(C) The Authors 2010. The online version of this article is published within an Open Access environment subject to the conditions of the Creative Commons Attribution-NonCommercial-ShareAlike licence $<$ http://creativecommons.org/licenses/by-nc-sa/2.5/ $>$. The written permission of Cambridge University Press must be obtained for commercial re-use.

\title{
Novel findings on the metabolic effects of the low glycaemic carbohydrate isomaltulose (Palatinose ${ }^{\mathrm{TM}}$ )
}

\author{
Ines Holub ${ }^{1}$, Andrea Gostner ${ }^{1}$, Stephan Theis ${ }^{2}$, Leszek Nosek ${ }^{3}$, Theodor Kudlich ${ }^{1}$, Ralph Melcher ${ }^{1}$ \\ and W. Scheppach ${ }^{4}$ \\ ${ }^{1}$ Department of Medicine II, Division of Gastroenterology, University of Würzburg, Versbacher Strasse 5, D-97080 Würzburg, \\ Germany \\ ${ }^{2}$ Suedzucker AG and BENEO, Wormser Strasse 11, D-67283 Obrigheim/Pfalz, Germany \\ ${ }^{3}$ Profil Institut für Stoffwechselforschung GmbH, Hellersbergstrasse 9, D-41460 Neuss, Germany \\ ${ }^{4}$ Juliusspital Würzburg, Department of Medicine, Juliuspromenade 19, D-97070 Würzburg, Germany
}

(Received 25 February 2009 - Revised 14 December 2009 - Accepted 18 December 2009 - First published online 9 March 2010)

\begin{abstract}
The slow digestible disaccharide isomaltulose (iso; Palatinose ${ }^{\mathrm{TM}}$ ) is available as novel functional carbohydrate ingredient for manufacturing of low glycaemic foods and beverages. Although basically characterised, various information on physiological effects of iso are still lacking. Thus, the objective of the present study was to expand scientific knowledge of physiological characteristics of iso by a set of three human intervention trials. Using an ileostomy model, iso was found to be essentially absorbed, irrespective of the nature of food (beverage and solid food). Apparent digestibility of $50 \mathrm{~g}$ iso from two different meals was 95.5 and $98.8 \%$; apparent absorption was 93.6 and $96.1 \%$, respectively. In healthy volunteers, a single dose intake of iso resulted in lower postprandial blood glucose and insulin responses than did sucrose (suc), while showing prolonged blood glucose delivery over $3 \mathrm{~h}$ test. In a 4-week trial with hyperlipidaemic individuals, regular consumption of $50 \mathrm{~g} / \mathrm{d}$ iso within a Western-type diet was well tolerated and did not affect blood lipids. Fasting blood glucose and insulin resistance were lower after the 4-week iso intervention compared with baseline. This would be consistent with possible beneficial metabolic effects as a consequence of the lower and prolonged glycaemic response and lower insulinaemic burden. However, there was no significant difference at 4 weeks after iso compared with suc. In conclusion, the study shows that iso is completely available from the small intestine, irrespective of food matrix, leading to a prolonged delivery of blood glucose. Regular iso consumption is well tolerated also in subjects with increased risk for vascular diseases.
\end{abstract}

Isomaltulose: Metabolic markers: Ileostoma: Hyperlipidaemia: Low glycaemic foods

There is growing interest in the glycaemic properties of foods and the possible contribution of glycaemic properties to nutrition and health ${ }^{(1)}$. Over the last decades, a growing body of research has shown that diets based on low glycaemic and low insulinaemic foods reduce the risk of developing diabetes, obesity and CVD, improve blood glucose control in people with diabetes, may influence blood lipids and can be useful for weight management ${ }^{(2-4)}$. Furthermore, low glycaemic and low insulinaemic foods are considered as favourable as they could contribute to a prolonged feeling of satiety and a sustained energy release with further implications for physical and mental performance ${ }^{(5,6)}$.

Conventional carbohydrate ingredients for the manufacturing of composite foods, like processed starch, glucose as such, glucose syrups, maltodextrins but also sucrose (suc) are predominantly more rapidly digested carbohydrates that induce a relatively high glycaemic and insulinaemic response. Even so, food manufacturers have the possibility to modify the glycaemic impact of foods by substitution of these more rapidly digested and thus high glycaemic carbohydrates by low glycaemic carbohydrate alternatives. Isomaltulose (iso; Palatinose ${ }^{\mathrm{TM}}$ ) is a recent example of such an alternative carbohydrate ingredient.

Iso is a reducing disaccharide comprised of glucose and fructose joined by an $\alpha-1,6$-glycosidic bond. iso is naturally present in honey and sugarcane juice ${ }^{(7)}$. Commercial iso (Palatinose $^{\mathrm{TM}}$ ) is manufactured from food-grade suc by enzymatic rearrangement of the glycosidic linkage followed by crystallisation ${ }^{(8-10)}$. Iso has been used as sugar in Japan and other Asian countries for more than two decades. In the European Union, it was approved as Novel Food in $2005^{(11)}$ and is marketed as generally recognised as safe in the $\mathrm{US}^{(12)}$.

Taste and appearance of iso are similar to suc, and the sweetness is about half of that of suc. In contrast to suc, iso is hardly utilised by oral plaque bacteria and is thus noncariogenic $^{(13)}$. Due to its more stable $\alpha-1,6$-glycosidic bond iso is slowly, though completely, hydrolysed by small intestinal disaccharidases. In studies utilising human small intestinal mucosa homogenates as enzyme source, iso was hydrolysed with $\mathrm{V}_{\max }$ of $26-45 \%$ compared with suc ${ }^{(7)}$. The released

Abbreviations: GI, glycaemic index; GL, glycaemic load; HOMA-IR, homeostasis model assessment for insulin resistance; iso, isomaltulose; suc, sucrose. 
monosaccharides glucose and fructose are absorbed and metabolised. Due to the slower release and absorption of the monosaccharides, blood glucose and insulin response after oral administration were found to rise slower and reach lower maxima than after suc administration. The glucose supply is thus sustained over a longer period of time ${ }^{(7)}$. With a calculated glycaemic index (GI) of 32 , iso is a low glycaemic carbohydrate ${ }^{(14)}$.

The digestibility characteristics of iso have been particularly derived from earlier in vitro and animal studies. Up to present, no human data were available whether iso, when incorporated in complex food and beverages, is indeed a slowly digestible, yet fully available carbohydrate. The studies carried out with iso so far are mainly single-meal trials in healthy human subjects. Thus, health effects of regular and longer-term consumption of iso are hardly known particularly in subjects with increased risk for non-communicable diseases.

The objectives of the present study were therefore: (a) to investigate the actual availability, i.e. digestibility and absorption of iso from human small intestine after consumption of iso-rich meals; (b) to examine glucose and insulin response to iso intake in healthy subjects; (c) to study possible health effects of a regular consumption of iso in volunteers with hyperlipidaemia.

\section{Subjects and methods}

A total of three human intervention trials were performed. The small intestinal digestion and absorption of iso incorporated in different foods were examined in a sequential, not blinded trial in healthy ileostomates. Trials 2 and 3 were performed in a double-blind, randomised, controlled cross-over design. Blood glucose and insulin profiles were determined over $3 \mathrm{~h}$ after the intake of iso in healthy subjects. Trial 3 investigated the effects of regular consumption of iso in overweight hyperlipidaemic subjects.

\section{Trial 1 - ileostomy study on the digestion and absorption of} isomaltulose

Ten healthy subjects with an end ileostomy without ileal resection participated in the trial (eight women and two men; mean age of 47 years, range 33-67 years). They had undergone colectomy between 1 and 28 years (mean 10 years) before the study; the underlying conditions were Crohn's disease ( $n$ 6), ulcerative colitis ( $n$ 3) or familial adenomatous polyposis $(n 1)$.

On two separate days, the participants consumed a test meal including $50 \mathrm{~g}$ iso for breakfast after overnight fasting. The two study days were separated by at least $6 \mathrm{~d}$. All the test meal products were prepared and supplied by Suedzucker AG (Mannheim/Ochsenfurt, Germany). Test meal 1 was a beverage $(500 \mathrm{ml})$; meal 2 consisted of a beverage $(250 \mathrm{ml})$ and biscuits $(140 \mathrm{~g})$ each containing $25 \mathrm{~g}$ iso. The $140 \mathrm{~g}$ biscuits provided $2.3 \mathrm{MJ}, 79.2 \mathrm{~g}$ carbohydrate, $9.8 \mathrm{~g}$ protein, $44.8 \mathrm{~g}$ fat. Both the test meals were consumed within 5-7 min. After $5 \mathrm{~h}$, the subjects were served a standardised lunch (400 g lasagne: $2 \cdot 8 \mathrm{MJ}, 56 \mathrm{~g}$ carbohydrate, $24 \mathrm{~g}$ protein, $40 \mathrm{~g}$ fat). The ileostomy bags were collected immediately before and hourly within the next $8 \mathrm{~h}$ after the test meal intake. The ileostomy effluents were weighed, homogenised, and aliquots were frozen at $-20^{\circ} \mathrm{C}$ until analysis. To avoid bacterial degradation of the effluent, antibiotic solutions ( $5 \mathrm{ml}$ ampicillin and $5 \mathrm{ml}$ metronidazole) were added to each new applied bag. The suitability was confirmed in pre-tests with spiked ileostomy samples.

The study was conducted according to the guidelines laid down in the Declaration of Helsinki and all procedures involving human subjects were approved by the local Ethics Committee of the Faculty of Medicine, University of Würzburg, Germany. Written informed consent was obtained from all the subjects.

Trial 1 was carried out at University of Würzburg, Department of Medicine II, Division of Gastroenterology, Grombühlstr. 12, D-97 080 Würzburg, Germany.

Analytic procedures. Ileostomy fluid homogenate samples were analysed for iso, as well as glucose and fructose as hydrolysis products using GC (Agilent 6890) and a capillary fused silica column CP-Sil 8CB $(15 \mathrm{~m} \times 150 \mu \mathrm{m} \times 0.15 \mu \mathrm{m})$ with FID. Carrier gas was helium. The temperature program was $80^{\circ} \mathrm{C}$ for $1 \mathrm{~min}, 30^{\circ} \mathrm{C} / \mathrm{min}$ to $170^{\circ} \mathrm{C}, 10^{\circ} \mathrm{C} / \mathrm{min}$ to $350^{\circ} \mathrm{C}$ ( $3 \mathrm{~min})$. The method was validated beforehand. Linearity of the GC method was confirmed by analysis of standard solutions of different iso concentrations with a (linear) coefficient of correlation of 0.99993. In ileostomy samples free of any additions, iso co-eluted only with negligible amounts $(<0.1 \%)$ of unknown compounds. Repeatability was calculated from ten replicate determinations of a sample (in each case completely separate sample preparation) with a coefficient of variation of $2.4 \%$ for the iso content and $0.06 \%$ for the retention time was obtained. Recovery determined by samples spiked at three concentration levels (10, 1 and $0.1 \%$ iso) was 96,100 and $111 \%$.

Sample preparation and derivatisation was carried out as follows. Approximately, $1 \mathrm{~g}$ of sample and $0.05 \mathrm{~g}$ Phenyl$\beta$-D-glucopyranoside (internal standard) were weighed with an accuracy of $\pm 0.1 \mathrm{mg}$. After addition of $1 \mathrm{ml}$ ultra-pure water and $7.95 \mathrm{ml}$ pyridine, sample was stirred for $30 \mathrm{~min}$. To $0.2 \mathrm{ml}$ of this sample, $0.8 \mathrm{ml}$ oxime reagent $(10 \mathrm{~g}$ hydroxyl ammonium hydrochloride in $90 \mathrm{ml}$ pyridine) was added and warmed for $30 \mathrm{~min}$ to $60^{\circ} \mathrm{C}$. After cooling to room temperature, $0.4 \mathrm{ml}$ pyridine and $0.5 \mathrm{ml} \mathrm{N}$-methyl- $N$-trimethylsilyltrifluoracetamide (MSTFA) were added to $0.1 \mathrm{ml}$ of this solution. After warming to $60^{\circ} \mathrm{C}$ for another $30 \mathrm{~min}$ and cooling down, the sample was directly injected into the GC. Concentrations of saccharides were calculated based on peak area ratios of the sample compared to standard chromatograms.

Calculations. The apparent digestibility of iso was calculated as intake of iso $(50 \mathrm{~g})$ minus excretion of iso $(\mathrm{g} / 8 \mathrm{~h})$ as a percentage of intake. Furthermore, the absorption was calculated as intake of carbohydrate amount ( $50 \mathrm{~g}$ iso) minus excretion of carbohydrate amount $(\mathrm{g} / 8 \mathrm{~h}$; sum of iso and of glucose and fructose as resulting monosaccharides from the intestinal hydrolysis of iso) as a percentage of intake.

\section{Trial 2 - blood glucose and insulin response study}

A total of ten healthy subjects (nine female, one male, age: 30.9 (SD 8.5) years; BMI: 23.3 (SD 2.8) kg/m²) were studied on two study days with respect to their blood glucose and insulin response over $3 \mathrm{~h}$ following ingestion of either $50 \mathrm{~g}$ 
of iso (Palatinose ${ }^{\mathrm{TM}}$ ) or suc dissolved in 0.5 litre water. Subjects came to the institute having fasted and refrained from smoking for $12 \mathrm{~h}$. To obtain baseline values, capillary blood glucose was measured (from the fingertip), and venous blood for insulin determination was taken via indwelling cannula inserted in a suitable forearm vein. Thereafter, the subjects received one portion of the iso or suc drink that was at room temperature and was ingested within $5 \mathrm{~min}$.

Measurements of postprandial capillary blood glucose concentrations and blood sampling for determination of insulin in plasma were performed over $3 \mathrm{~h}$ at $15,30,45,60,90$, 120,150 and $180 \mathrm{~min}$ after ingestion of the test food.

Capillary blood glucose measurements were performed using a Super GL analyzer (Hitado, Delecke-Möhnesee, Germany), utilising the glucose oxidase technique. Measurements were performed on the whole blood haemolysate in a flow chamber using membrane-bound glucose oxidase. Insulin was analysed using an electrochemiluminescence immunoassay (Elecsys ${ }^{\circledR}$ 1010/2010/MODULAR ANALYTICS E170, Roche Diagnostics GmbH, Mannheim, Germany).

For each test food and individual subject, incremental area under the curves above baseline of blood glucose and plasma insulin concentrations was calculated.

The study was conducted according to the guidelines laid down in the Declaration of Helsinki and all procedures involving human subjects were approved by the local Ethics Committee of the Ärztekammer Nordrhein, Düsseldorf, Germany. Written informed consent was obtained from all the subjects.

Trial 2 was carried out at the Profil Institut für Stoffwechselforschung GmbH, Hellersbergstr. 9, D-41460 Neuss, Germany.

\section{Trial 3 - effects of regular consumption of isomaltulose in hyperlipidaemic subjects}

Seventy-four volunteers were screened to recruit twenty subjects fulfilling all inclusion and none of exclusion criteria. All twenty volunteers recruited for the trial completed the study (twelve women and eight men). Before entry, the subjects were screened for their blood lipid status and were considered hyperlipidaemic with baseline cholesterol level $>6.5 \mathrm{mmol} / \mathrm{l}$ and/or TAG level $>2.3 \mathrm{mmol} / \mathrm{l}$, i.e., levels usually associated with a higher risk for $\mathrm{CVD}^{(15)}$. Exclusion criteria were: age $<18$ years; $\mathrm{BMI}<25$ or $>40 \mathrm{~kg} / \mathrm{m}^{2}$; history of severe chronic medical disease, including gastrointestinal diseases and diabetes; glucocorticoid therapy; pregnancy; unusual dietary habits.

The study was designed as a randomised, double-blind, controlled, cross-over trial with two 4-week test periods separated by a 4 -week washout phase. During the two 4-week study periods, the participants consumed a controlled diet. The diets were isoenergetic and composed as a typical Western diet (low-fibre and high-fat), containing the same basic foods and test products, except that the test products provided either $50 \mathrm{~g} / \mathrm{d}$ iso or $50 \mathrm{~g} / \mathrm{d}$ suc. Comprising $50 \mathrm{~g} / \mathrm{d}$ iso or suc, the diets finally provided $47 \%$ of energy as carbohydrates, $39 \%$ of energy as fat, $14 \%$ of energy as protein and $1.4 \mathrm{~g} / \mathrm{MJ}$ dietary fibre (Table 1 ). Iso and suc were included in sweet foods (pudding, biscuits, toffees) and beverages (milk drinks, soft drinks, tea beverages). All the test
Table 1. Cross-over study: composition of the study diet

\begin{tabular}{|c|c|c|c|c|}
\hline & \multicolumn{2}{|c|}{ Women (n 12) } & \multicolumn{2}{|c|}{ Men $(n 8)$} \\
\hline & Mean & SD & Mean & SD \\
\hline Metabolisable energy (MJ) & $9 \cdot 2$ & 0.3 & $11 \cdot 6$ & 0.2 \\
\hline Carbohydrate ( $\%$ of energy) & $47 \cdot 3$ & 1.8 & $47 \cdot 1$ & 1.6 \\
\hline Protein ( $\%$ of energy) & $14 \cdot 0$ & 0.6 & $14 \cdot 4$ & $1 \cdot 1$ \\
\hline Fat (\% of energy) & 38.9 & 1.7 & $38 \cdot 1$ & 1.6 \\
\hline Dietary fibre (g/MJ) & 1.4 & 0.3 & 1.4 & 0.3 \\
\hline
\end{tabular}

The energy, macronutrient and dietary fibre intake were calculated with PRODI expert 4.5 software (Wissenschaftliche Verlagsgesellschaft $\mathrm{mbH}$, Stuttgart, Germany). In case of ready-to-eat foods (Eismann Tiefkühl-Heimservice, Mettmann, Germany; Hofmann Menü-Manufaktur, Boxberg-Schweigern, Germany), the data were based on manufacturer information.

products were prepared and supplied by Suedzucker AG. As shown in Table 2, a $7 \mathrm{~d}$ rotating menu including readyto-eat foods (Eismann Tiefkühl-Heimservice, Mettmann, Germany; Hofmann Menü-Manufaktur, Boxberg-Schweigern, Germany) was used. Meals were weighed and packaged in the metabolic unit of the clinic. All meals were given to the subjects to be eaten at home. Additional food was not allowed, the participants were instructed to completely consume the provided portions. Water, tea and coffee were allowed ad libitum. Alcohol consumption was restricted to $500 \mathrm{ml}$ beer or $250 \mathrm{ml}$ wine per week. The macronutrient composition of the diet was calculated with PRODI expert 4.5 software (Wissenschaftliche Verlagsgesellschaft mbH, Stuttgart, Germany). Food was given to the subjects every other day in the metabolic unit by a study nutritionist. This regular contact was maintained to ensure volunteers' compliance. In addition, the subjects were advised to return all blank packages of the test food at the following visit. Body weight was measured at entry and then at $2 \mathrm{~d}$ intervals in the first week and thereafter at weekly intervals in both phases.

The subjects kept a daily record of subjective gastrointestinal parameters, stool frequency and stool consistency during the two 4-week study periods. Abdominal distension, flatulence, abdominal pain and nausea were scored on semi-quantitative scales from 0 (absent) to 3 (severe). Stool consistency was also scored from 1 (hard) to 4 (watery).

Twenty-four-hour urine collections were obtained before and after each test period and analysed for electrolytes and albumin. At the same time venous blood was taken in the morning after $12 \mathrm{~h}$ overnight fasting period and analysed for general safety measurements as well as metabolic and risk measurements. Routine biochemical measurements and blood lipid status were analysed in the Central Laboratory of the University Hospital. In addition, tests for the assessment of renal and liver function, blood glucose, $\mathrm{HbA}_{1 \mathrm{c}}$, C-reactive protein, uric acid, electrolytes, blood coagulation tests and a complete blood cell count were performed. Serum and plasma samples for the determination of fructosamine, proinsulin, insulin, C-peptide, adiponectin, leptin, NEFA, oxidised $\mathrm{LDL}$ were stored at $-80^{\circ} \mathrm{C}$ until further analysis.

The study was conducted according to the guidelines laid down in the Declaration of Helsinki and all procedures involving human subjects were approved by the local Ethics Committee of the Faculty of Medicine, University of Würzburg, Germany. Written informed consent was obtained from all the subjects. 
Table 2. Cross-over study: $7 \mathrm{~d}$ rotating menu containing basic diet and test products for men

\begin{tabular}{|c|c|c|c|c|c|c|c|}
\hline & Monday & Tuesday & Wednesday & Thursday & Friday & Saturday & Sunday \\
\hline Breakfast & $\begin{array}{l}145 \mathrm{~g} \text { bun } \\
20 \mathrm{~g} \text { butter } \\
20 \mathrm{~g} \text { cream cheese } \\
25 \mathrm{~g} \text { vegetable paste } \\
200 \mathrm{ml} \mathrm{drink}^{*}\end{array}$ & $\begin{array}{l}145 \mathrm{~g} \text { bun } \\
20 \mathrm{~g} \text { butter } \\
30 \mathrm{~g} \text { soft cheese } \\
200 \mathrm{ml}^{\text {drink }}{ }^{*}\end{array}$ & $\begin{array}{l}145 \mathrm{~g} \text { bun } \\
20 \mathrm{~g} \text { butter } \\
20 \mathrm{~g} \text { cream cheese } \\
45 \mathrm{~g} \text { ham } \\
200 \mathrm{ml} \mathrm{drink}^{*}\end{array}$ & $\begin{array}{l}145 \mathrm{~g} \text { bun } \\
20 \mathrm{~g} \text { butter } \\
30 \mathrm{~g} \text { meat paste } \\
200 \text { ml drink }^{*}\end{array}$ & $\begin{array}{l}145 \mathrm{~g} \text { bun } \\
20 \mathrm{~g} \text { butter } \\
40 \mathrm{~g} \text { cheese } \\
200 \mathrm{ml} \mathrm{drink}^{*}\end{array}$ & $\begin{array}{l}90 \mathrm{~g} \text { bun } \\
80 \mathrm{~g} \text { croissants } \dagger \\
20 \mathrm{~g} \text { butter } \\
20 \mathrm{~g} \text { cream cheese } \\
25 \mathrm{~g} \text { vegetable paste } \\
200 \mathrm{ml} \mathrm{drink}^{\star}\end{array}$ & $\begin{array}{l}90 \mathrm{~g} \text { bun } \\
80 \mathrm{~g} \text { croissants } \dagger \\
20 \mathrm{~g} \text { butter } \\
30 \mathrm{~g} \text { meat paste } \\
200 \mathrm{ml} \mathrm{drink}^{*}\end{array}$ \\
\hline Snack & One kiwi & One apple & $150 \mathrm{~g}$ fruit yoghurt & One kiwi & One apple & One banana & $100 \mathrm{~g}$ pudding ${ }^{*}$ \\
\hline Lunch & $\begin{array}{l}\text { Ready-to-eat menuł } \\
125 \text { ml drink }^{*} \\
100 \text { g pudding }^{\star}\end{array}$ & $\begin{array}{l}400 \mathrm{~g} \text { lasagne } \dagger \\
150 \mathrm{~g} \text { fruit yoghurt } \\
250 \mathrm{ml} \mathrm{drink}^{*}\end{array}$ & $\begin{array}{l}\text { Ready-to-eat menuł } \\
125 \text { ml drink }^{*} \\
100 \text { g pudding }^{*}\end{array}$ & $\begin{array}{l}\text { Ready-to-eat menuf } \\
150 \mathrm{~g} \text { fruit yoghurt } \\
250 \mathrm{ml} \mathrm{drink}^{*}\end{array}$ & $\begin{array}{l}\text { Ready-to-eat menuł } \\
125 \mathrm{ml} \mathrm{drink}^{*} \\
100 \mathrm{~g} \mathrm{pudding}^{\star}\end{array}$ & $\begin{array}{l}\text { Ready-to-eat menuł } \\
125 \mathrm{ml} \mathrm{drink}^{*} \\
100 \mathrm{~g} \mathrm{pudding}^{\star}\end{array}$ & $\begin{array}{l}\text { Ready-to-eat menuf } \\
250 \mathrm{ml} \mathrm{drink}^{*}\end{array}$ \\
\hline Snack & $55 \mathrm{~g} \mathrm{biscuits}^{\star}$ & $\begin{array}{l}20 \mathrm{~g} \mathrm{soft} \mathrm{drops}^{*} \\
200 \mathrm{ml} \text { milk } \\
30 \mathrm{~g} \mathrm{cornflakes}\end{array}$ & $55 \mathrm{~g} \mathrm{biscuits}^{\star}$ & $\begin{array}{l}20 \text { g fudges }^{*} \\
200 \mathrm{ml} \mathrm{milk}\end{array}$ & $\begin{array}{l}55 \mathrm{~g} \mathrm{biscuits}^{\star} \\
200 \mathrm{ml} \mathrm{milk}\end{array}$ & $20 \mathrm{~g}$ soft drops ${ }^{\star}$ & $\begin{array}{l}150 \mathrm{~g} \text { fruit curd } \\
\text { One apple }\end{array}$ \\
\hline Dinner & $\begin{array}{l}250 \mathrm{~g} \text { salami baguette } \\
60 \mathrm{~g} \text { sausage } \\
\text { One tomato }\end{array}$ & $\begin{array}{l}180 \mathrm{~g} \text { brown bread } \\
20 \mathrm{~g} \text { margarine } \\
40 \mathrm{~g} \text { cheese } \\
60 \mathrm{~g} \text { meatball } \dagger \\
100 \mathrm{~g} \text { cuke }\end{array}$ & $\begin{array}{l}300 \mathrm{~g} \text { quiche } \dagger \\
\text { One tomato }\end{array}$ & $\begin{array}{l}\text { Baked camembert } \\
90 \mathrm{~g} \text { brown bread } \\
100 \mathrm{~g} \text { curd } \\
200 \mathrm{ml} \text { orange juice }\end{array}$ & $\begin{array}{l}135 \mathrm{~g} \text { brown bread } \\
20 \mathrm{~g} \text { margarine } \\
25 \mathrm{~g} \text { vegetable paste } \\
80 \mathrm{~g} \text { meatball } \dagger\end{array}$ & $\begin{array}{l}\text { Filled flaky pastry } † \\
\text { One tomato } \\
150 \mathrm{~g} \text { fruit yoghurt }\end{array}$ & $\begin{array}{l}165 \mathrm{~g} \text { salami pizza } \\
150 \mathrm{~g} \text { fruit yoghurt }\end{array}$ \\
\hline
\end{tabular}

The calculated daily energy was $11.6 \mathrm{MJ}$ for men. The menu for women was lower in energy $(9.2 \mathrm{MJ})$ but containing the same foods. Each ready-to-eat menu contained meat and side dishes. Total weight was $480-600 \mathrm{~g}$.

* Drink/food containing isomaltulose or sucrose.

† Ready-to eat food by Eismann Tiefkühl-Heimservice, Mettmann, Germany.

‡Ready-to-eat food by Hofmann Menü-Manufaktur, Boxberg-Schweigern, Germany. 
Trial 3 was carried out at University of Würzburg, Department of Medicine II, Division of Gastroenterology, Grombühlstr. 12, D-97 080 Würzburg, Germany.

Mean transit time and stool weight. Mean transit time was measured from days 21-23 of each study period using the single stool method of Cummings \& Wiggins ${ }^{(16)}$ and radiopaque markers (P \& A Mauch, Münchenstein, Switzerland) as described previously by Gostner et al. ${ }^{(17)}$. From days $24-26$ of each study period, stools were collected for quantitative assessment. Each stool was collected separately, frozen and stored at $-25^{\circ} \mathrm{C}$. After completion of the study, stool samples were thawed, and stool wet weight and faecal $\mathrm{pH}$ value were recorded. Three-day stool collections were pooled using a grinder. Faecal dry weight was measured after lyophilisation (Gamma IA apparatus; Christ, Osterode, Germany) of an aliquot to a constant weight.

Biochemical analyses. Cholesterol, TAG, HDL cholesterol and LDL cholesterol in serum were analysed using colorimetric enzyme kits (Roche Diagnostics). apo A1 and apo $\mathrm{B}_{100}$ were measured immuno-turbidimetrically (Roche Diagnostics). $\mathrm{HbA}_{1 \mathrm{c}}$ measurement was performed by HPLC, and fructosamine was determined using an enzymatic colorimetric assay kit (Boehringer, Mannheim, Germany). Venous blood glucose samples were analysed by hexokinase method (Roche Diagnostics). Proinsulin concentration was determined using a RIA kit (Linco Research, St Charles, MO, USA). Serum insulin and C-peptide were measured by RIA (Schering GmbH, Berlin, Germany). The homeostasis model assessment for insulin resistance (HOMA-IR) was determined for each individual according to Matthews et al. ${ }^{(18)}$. Oxidised LDL was determined in plasma samples using an ELISA kit (Mercodia, Uppsala, Sweden). NEFA level was determined by enzymatic colorimetric assay kit (Wako Chemicals GmbH, Neuss, Germany). Adiponectin concentration was measured using a RIA kit (Linco Research). Leptin was analysed in serum probes with a RIA kit (Mediagnost, Reutlingen, Germany).

\section{Statistical analysis}

Statistical analyses were carried out using SPSS for Windows version 14.0.1. Values are given as mean values and standard deviations. The non-parametric Wilcoxon rank sum test for paired data was used to determine the specific differences between iso and suc (trials 2 and 3 ) and between the two test meals (trial 1). Differences were considered to be significant at $P<0.05$.

In addition, for blood lipids, measurements of carbohydrate metabolism, adipocytokines and risk factors (trial 3), Wilcoxon test was performed to test for significant differences between baseline and 4-week measurements within each treatment.

\section{Results}

\section{Trial 1 - ileostomy study}

The amount of iso excreted after intake of both the test meals was very low, corresponding to $4.5 \%$ (test meal 1) and $1.2 \%$ (test meal 2) of intake, indicating a high apparent digestibility and absorption, unaffected by the nature of the meal (liquid $v$. solid). After consumption of $500 \mathrm{ml}$ beverage including $50 \mathrm{~g}$ iso (meal 1), the determined apparent digestibility was $95.5 \%$, ranging from 75.6 to $100 \%$ (median: $99.1 \%$ ). The apparent absorption rate of ingested iso from test meal 1 was estimated to be $93.6 \%$ (range: 69.3-99.8\%; median: $98.1 \%$ ). Similar results were found after consumption of a combination of $250 \mathrm{ml}$ beverage and $140 \mathrm{~g}$ biscuits including $50 \mathrm{~g}$ iso. The determined apparent digestibility was $98.8 \%$ (range: 95.3-100\%; median: 99.5\%) and apparent absorption was $96.1 \%$ (range: $88.6-99.6 \%$; median: $97.7 \%$ ). Digestibility and absorption of iso were almost complete in both the tests. Thus, in this assay, the nature of the meal (liquid or solid) did not significantly influence the digestibility and absorption of iso. Data are shown in Fig. 1.

\section{Trial 2 - blood glucose and insulin response study}

The mean $3 \mathrm{~h}$ blood glucose and insulin response curves for the $50 \mathrm{~g}$ portions of suc and iso are shown in Fig. 2. Iso produced the lowest blood glucose response curve (incremental area under the curves: 118 (SD 54) v. 184 (SD 70) $\mathrm{min} \times$ $\mathrm{mmol} / \mathrm{l} ; P=0 \cdot 037$ ), increasing gradually and only moderately. A plateau rather than a peak was obtained of about $5.8 \mathrm{mmol} / \mathrm{l}$ approximately $15-30 \mathrm{~min}$ later than the peak with suc. After the maximum, blood glucose slowly declined and remained above baseline until the end of testing. After intersection of blood glucose profiles of suc and iso at about $60-90 \mathrm{~min}$, blood glucose with iso remained higher for more than $90 \mathrm{~min}$.

The insulin response for the saccharides was directly proportional to their glycaemic response, both in the magnitude and shape of the response curve (incremental area under the curves: 15208 (SD 8639) v. 23347 (SD 14 451) $\mathrm{min} \times \mathrm{pmol} / \mathrm{l}$; $P=0.005)$. Iso evoked the lowest insulin response with a maximum of $227.8 \mathrm{pmol} / \mathrm{l}$, which is more than $50 \%$ lower compared with suc $(470 \cdot 1 \mathrm{pmol} / \mathrm{l})$.

Trial 3 - effects of regular consumption of isomaltulose in hyperlipidaemic subjects

Subjects and compliance. Twenty volunteers, aged 21-61 years (mean 48.2 years) completed the study (twelve women

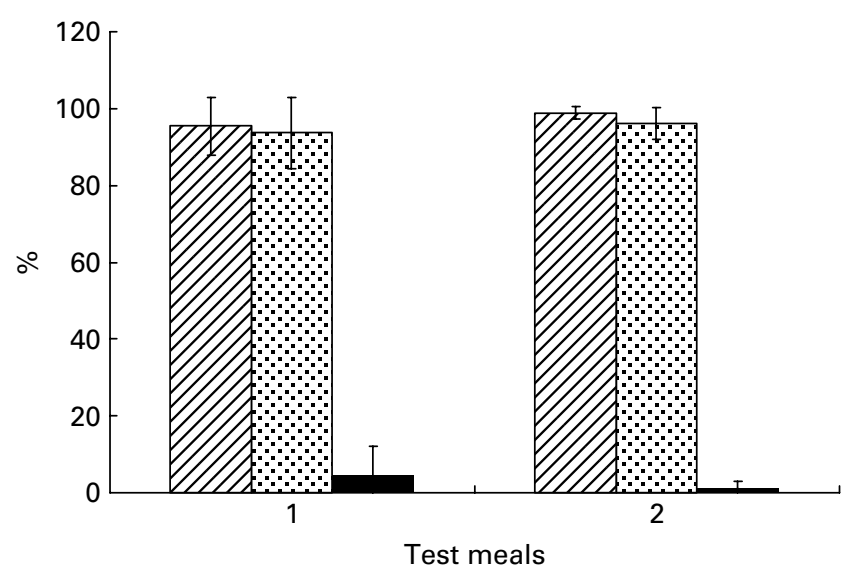

Fig. 1. lleostomy study: apparent digestibility, absorption and excretion of isomaltulose from different meals.1, Test meal 1 was a beverage $(500 \mathrm{ml})$ containing $50 \mathrm{~g}$ isomaltulose; 2 , test meal 2 was a beverage $(250 \mathrm{ml})$ and biscuits $(140 \mathrm{~g})$ together containing $50 \mathrm{~g}$ isomaltulose. $\mathbb{\mathbb { N }}$, Digestibility; ๑. absorption; $\mathbf{\square}$, isomaltulose excretion. 

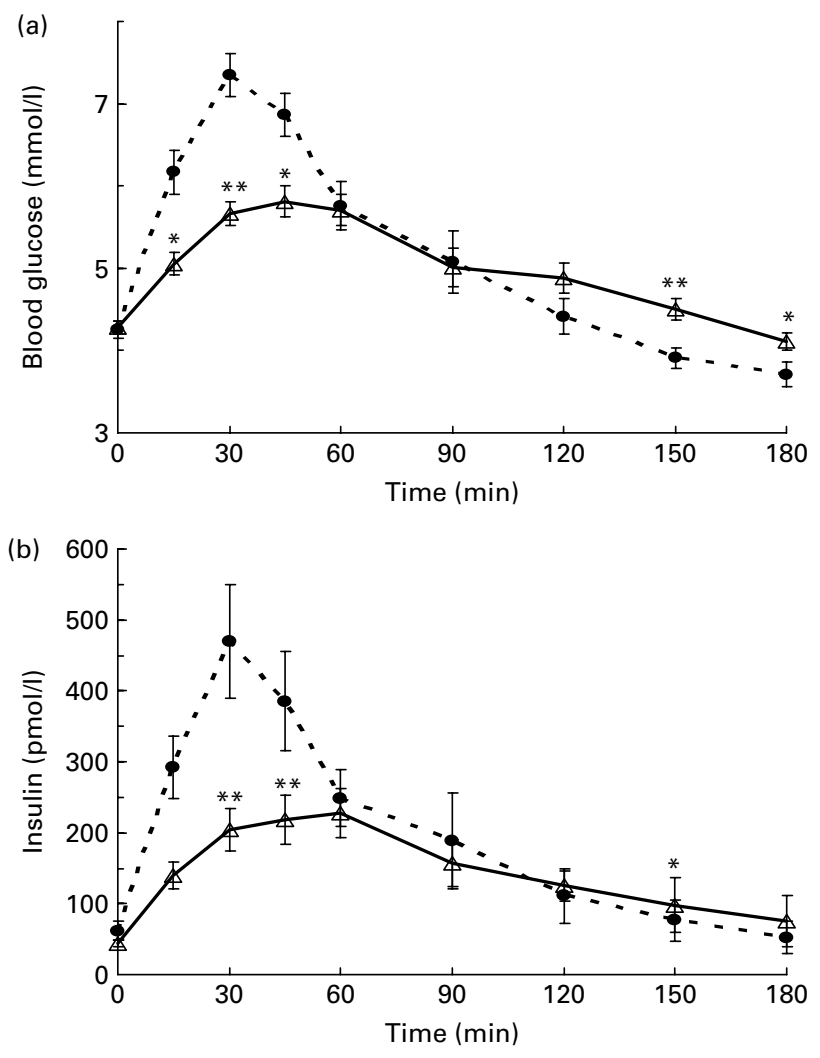

Fig. 2. Blood glucose and insulin response study. (a) Blood glucose profiles of $50 \mathrm{~g}$ isomaltulose $(\triangle)$ and sucrose $(\bullet)$ over $3 \mathrm{~h}$. (b) Insulin profiles of $50 \mathrm{~g}$ isomaltulose and sucrose over $3 \mathrm{~h}$. Mean values were significantly different: ${ }^{\star} P<0.05,{ }^{\star \star} P<0.01$ by Wilcoxon test for paired data.

and eight men; no drop-out). The two 4-week study periods had the same number of subjects. The mean BMI of the women was $31.9(\mathrm{SD} 3.1) \mathrm{kg} / \mathrm{m}^{2}$ and of the men 33.4 (SD 2.4$) \mathrm{kg} / \mathrm{m}^{2}$. Mean BMI and mean body weight did not differ between the treatments. There was a slight and similar reduction in body weight with both the treatments $(-0.9$ (SD 1.0) $\mathrm{kg}$ with iso and -1.1 (SD 0.7) $\mathrm{kg}$ with suc). Subjective intestinal characteristics such as distension were usually rated as low or unchanged and did not significantly differ between iso and suc. With each treatment, pain and nausea were scored as absent. In conclusion, the daily consumption of $50 \mathrm{~g}$ iso was well accepted and tolerated by the subjects.

The compliance of volunteers was maintained throughout the study as also indicated by the virtually complete return $(97 \%)$ of blank packages of test products.

Routine blood measurements. Routine biochemical and standard clinical measurements for the assessment of renal and liver function, clotting (prothrombin time and partial thromboplastin time) and blood cell counts were not significantly different between both the treatments. The values remained in the normal range with both interventions (data not shown).

Urine and stool measurements. Routine urine measurements, including $\mathrm{Ca}, \mathrm{K}, \mathrm{Na}$, phosphate and albumin excretion were comparable with both the treatments and remained in the normal range (data not shown).

Mean values of stool frequency and stool consistency were not significantly different between iso and suc intervention (data not shown). Furthermore, mean transit time (iso $47 \cdot 3$
(SD 13.4); suc 42.8 (SD 11.8)h) as well as wet weight (iso 151.1 (SD 55.8); suc 162.7 (SD 70.5) g/d), dry weight (iso 29.4 (SD 13.3); suc 32.2 (SD 14.8) g/d), faecal water content (iso 121.7 (SD 51.7); suc $130.6(\mathrm{SD} 59.8) \mathrm{g} / \mathrm{d}$ ) and $\mathrm{pH}$ (iso 7.3 (SD 0.3); suc $7.5(\mathrm{SD} 0.4) \mathrm{g} / \mathrm{d}$ ) were not influenced by iso intake and did not differ significantly between the treatments.

Blood lipids. No significant treatment difference was obtained for total cholesterol (baseline: iso 6.2 (SD 1.0) $v$. suc $6.2(\mathrm{SD} 1 \cdot 0) \mathrm{mmol} / \mathrm{l}$; week 4: iso 6.1 (SD 0.9) v. suc $6 \cdot 2$ (SD 0.9) $\mathrm{mmol} / \mathrm{l}$ ), HDL cholesterol (1.3 (SD 0.4) v. 1.3 (SD $0.4) \mathrm{mmol} / \mathrm{l} ; 1.3(\mathrm{SD} 0.4)$ v. 1.4 (SD 0.3) mmol/1), LDL cholesterol $(3.9$ (SD 1.0) v. 3.8 (SD 0.9) $\mathrm{mmol} / \mathrm{l} ; 3.8$ (SD 0.9) v. 3.8 (SD 1.0) mmol/l), TAG (2.2 (SD 1.2) v. 2.5 (SD 1.9) mmol/l; $2.4(\mathrm{SD} 1.4)$ v. $2.3(\mathrm{SD} 1.6) \mathrm{mmol} / \mathrm{l}$ ), apo $\mathrm{A} 1$ and apo $\mathrm{B}_{100}$ as well as LDL/HDL ratio and $\mathrm{Apo} \mathrm{B}_{100} / \mathrm{Apo} \mathrm{A} 1$ ratio.

Measurements of carbohydrate metabolism. The mean fasting levels of blood glucose, insulin, C-peptide, proinsulin, $\mathrm{HbA}_{1 \mathrm{c}}$, fructosamine and insulin resistance (HOMA-IR) at baseline were not significantly different, except values of blood glucose. Mean fasting levels at all time points were similar in the higher normal range or in the case of proinsulin slightly higher. There was no significant treatment difference. With both the interventions, there was a slight but statistically significant decrease in concentrations of C-peptide (baseline: iso $1.1(\mathrm{SD} 0.4) v$. suc $1.1(\mathrm{SD} 0.4) \mathrm{nmol} / \mathrm{l}$; week4: iso $1.0 \quad(\mathrm{SD} 0.4) \quad v$. suc $1.0(\mathrm{SD} \quad 0 \cdot 3) \mathrm{nmol} / \mathrm{l})$ and proinsulin $(17 \cdot 2$ (SD 11.4) v. 18.6 (SD 12.3) pmol/l; 15.1 (SD 12.8) v. 14.6 (SD 10.0) pmol/l). Significant lower fasting blood glucose levels $(5 \cdot 3(\mathrm{SD} 0 \cdot 5)$ v. $5 \cdot 0$ (SD 0.6) $\mathrm{mmol} / \mathrm{l} ; 4.9$ (SD 0.4) v. 4.9 (SD $0 \cdot 3) \mathrm{mmol} / \mathrm{l} ; P=0.002)$ together with reduced HOMA-IR (4.6 (SD 2.7) v. 4.8 (SD 2.6); 3.8 (SD 2.1) v. 3.9 (SD 1.7); $P=0.036)$ were noted after the 4 -week iso intervention
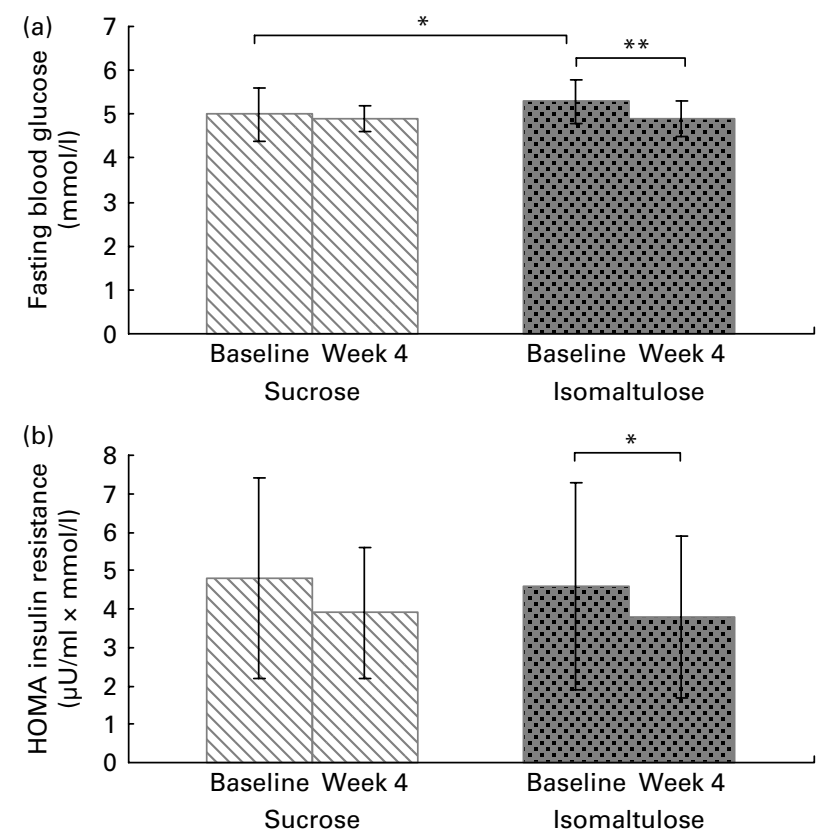

Fig. 3. Cross-over study. (a) Fasting blood glucose levels of twenty hyperlipidaemic subjects following consumption of either $50 \mathrm{~g}$ isomaltulose/d or $50 \mathrm{~g}$ sucrose/d for 4 weeks. (b) HOMA insulin resistance of twenty hyperlipidaemic subjects following consumption of either $50 \mathrm{~g}$ isomaltulose $/ \mathrm{d}$ or $50 \mathrm{~g}$ sucrose/d for 4 weeks. Mean values were significantly different: ${ }^{\star} P<0.05$, ${ }^{\star \star} P<0.01$ by Wilcoxon test for paired data. 
compared with baseline (Fig. 3), however, no significant differences in fasting blood glucose levels and HOMA-IR were observed at 4 weeks between iso and suc.

Adipocytokines and risk factors. Adiponectin levels were comparable with both the treatments. There was a slight and comparable reduction in leptin concentrations with iso and suc intervention. The cardiovascular risk factors oxidised LDL and NEFA were stable with iso consumption and did not differ significantly in comparison with suc (data not shown).

\section{Discussion}

To our knowledge, this is the first study investigating the digestibility and absorption of iso in vivo in human subjects. The ileostomy model applied here is a suitable method for evaluating absorption processes and was extensively used in many studies for determination of small intestinal digestion of carbohydrates ${ }^{(19-24)}$. Results from our ileostomy study with iso confirmed findings from earlier in vitro and animal studies $^{(7)}$ that iso is virtually completely digested and absorbed from the human small intestine, irrespective of the food matrix and the food consistency. Together, with the findings from the postprandial blood glucose and insulin determination after iso consumption, these results confirm that iso is completely, but very slowly hydrolysed and absorbed in the small intestine, leading to a prolonged delivery of blood glucose for metabolism. Thus, the present study confirms that iso is a completely available low glycaemic and low insulinaemic carbohydrate.

In the 4-week cross-over trial on the effects of regular iso consumption, iso was given within a controlled and typical Western diet (low-fibre and high-fat) in the form of a variety of foods like pudding, biscuits, toffees and beverages (Table 2). Iso and its products used in the present study were well accepted and $50 \mathrm{~g} / \mathrm{d}$ over the 4 -week test period was well tolerated by the participants.

The 4-week cross-over study was aimed to examine the effects of regular iso consumption instead of higher glycaemic ingredients in hyperlipidaemic subjects. To our knowledge, this is the first human intervention study looking at regular consumption of iso over a longer period. In the present study, blood lipids (cholesterol, LDL, HDL, TAG and apo) were not affected by low glycaemic carbohydrate iso. Oxidised LDL and NEFA levels stayed constant both with suc and iso. Relationships between dietary GI and blood lipid fractions have been assessed in several prospective observational studies. An inverse association between HDL cholesterol and dietary GI was found in many studies ${ }^{(25-27)}$, although one study detected no association ${ }^{(28)}$. Furthermore, observational studies showed that TAG levels tend to rise when GI or glycaemic load (GL) of the habitual diet increases. However, results from the intervention trials differed from those of observational studies. Opperman et al. ${ }^{(29)}$ have carried out a meta-analysis of fourteen randomised, controlled clinical trials to determine if low GI diets, compared with conventional or high GI diets, have beneficial effects on markers for lipid metabolism. In the studies reviewed, low GI diets caused a statistically significant improvement in total cholesterol concentrations but not in TAG, HDL and LDL cholesterol. Another meta-analysis by Livesey et al. ${ }^{(4)}$ demonstrated no clear evidence for a difference in TAG following lower GI/GL intervention, although TAG levels were reduced in those groups with the highest levels. In hyperlipidaemic subjects without diabetes, Jenkins et al. ${ }^{(30)}$ showed that 4 weeks on low GI diet could reduce total cholesterol and LDL cholesterol by about $10 \%$ and TAG by $20 \%$ compared with high GI diet. This indicates that influence of the overall dietary GI or GL on markers of lipid metabolism varies between studies. Moreover, it would be conceivable that more pronounced favourable effects of lower GI/GL intervention may particularly present in more symptomatic hyperlipidaemics.

With regard to carbohydrate metabolism, significant lower fasting blood glucose levels and insulin resistance (HOMAIR) were noted after 4-week iso compared with baseline, whereas these differences were non-significant with suc treatment. However, there were no significant differences between iso and suc at 4 weeks in any measurement of carbohydrate metabolism. Both the interventions slightly improved proinsulin and C-peptide levels. Most intervention trials looking at effects of GI/GL on carbohydrate metabolism were carried out in type 2 or type 1 diabetics. Meta-analyses demonstrated that studies in patients with type 2 diabetes showed beneficial effects of low GI/GL diets reflected in decreased $\mathrm{HbA}_{1 \mathrm{c}}$, fructosamine $^{(29,31)}$ as well as HOMA-IR, fasting blood glucose and insulin levels ${ }^{(4)}$. Data for subjects with unimpaired carbohydrate metabolism, however, are rare. Brand-Miller et al. ${ }^{(31)}$ reported a non-significant decrease in fructosamine in healthy subjects by low GI diets. In addition, Livesey et al. ${ }^{(4)}$ observed that for improvement in fasting blood glucose levels and glycated proteins, there is evidence that the effects are greatest among those with poorest glycaemic control. For reduction in fasting blood glucose, the threshold is about $5 \mathrm{mmol} / \mathrm{l}$. With reference to insulin levels, no treatment effects were determined for concentrations $<100 \mathrm{pmol} / \mathrm{l}^{(4)}$. Hence, our data are consistent with the literature. In subjects with more obvious disturbances in blood glucose control, such as people with impaired glucose tolerance or manifest diabetes, presumably more pronounced beneficial longer term effects may be possible as cause of the lower and prolonged glycaemic response and the lower insulinaemic burden associated with iso.

In conclusion, the present study confirms that iso is completely, but very slowly hydrolysed and absorbed from the human small intestine, irrespective of food matrix and consistency, leading to a prolonged delivery of blood glucose. Furthermore, the present study confirms that regular consumption of iso over longer terms is well tolerated also in subjects with increased risk for vascular diseases.

\section{Acknowledgements}

We thank K. Backhaus, D. Dorbath, E. Kelber, H. Lichtlein and A. Volk for excellent technical assistance; Margit Arenz and Tillmann Doerr of Suedzucker AG for development and preparation of the test products; Dierk Martin and Willi Kundel of Suedzucker AG, CRDS for analysis of ileostomy samples; the central laboratory of the University of Würzburg, Germany for routine blood and urine analyses. The present study was funded by Beneo-Palatinit, Mannheim, Germany, a member of the Südzucker Group. The study results and data contained in the publication have been developed by 
and/or for Beneo. Beneo reserves the exclusive right to use the results and data for possible health claim requests. The authors' responsibilities were as follows: I. H., A. G., S. T. and W. S. conceived and designed the study; I. H., A. G., T. K. were responsible for implementation of trials 1 and 3; L. N. was responsible for implementation of trial 2; I. H. was responsible for data analysis and interpretation and writing of the manuscript; A. G., S. T. and W. S. were responsible for the critical revision of the manuscript and its important intellectual content; R. M. and W. S. were responsible for study supervision. None of the authors had a conflict of interest. (S. T. is employed by Suedzucker AG.)

\section{References}

1. Howlett J \& Ashwell M (2008) Glycemic response and health: summary of a workshop. Am J Clin Nutr 87, suppl, 212S-216S.

2. Dickinson $\mathrm{S} \&$ Brand-Miller J (2005) Glycemic index, postprandial glycemia and cardiovascular disease. Curr Opin Lipidol 16, 69-75.

3. Augustin LS, Franceschi S, Jenkins DJ, et al. (2002) Glycemic index in chronic disease: a review. Eur J Clin Nutr 56, 1049-1071.

4. Livesey G, Taylor R, Hulshof T, et al. (2008) Glycemic response and health - a systematic review and meta-analysis: relations between dietary glycemic properties and health outcomes. Am J Clin Nutr 87, Suppl., 258S-268S.

5. Benton D \& Nabb S (2003) Carbohydrate, memory, and mood. Nutr Rev 61, S61-S67.

6. Siu PM \& Wong SH (2004) Use of the glycemic index: effects on feeding patterns and exercise performance. J Physiol Anthropol Appl Human Sci 23, 1-6.

7. Lina BAR, Jonker D \& Kozianowski G (2002) Isomaltulose (Palatinose): a review of biological and toxicological studies. Food Chem Toxicol 40, 1383-1389.

8. Mauch W \& Schmidt-Berg-Lorenz S (1964) Über den bakteriellenzymatischen Umlagerungsmechanismus Saccharose. Isomaltulose (6-( $\alpha$-D-Glucosyl)-D-Fruktose) (About the mechanism of bacterial-enzymatic rearrangement of sucrose. Isomaltulose (6-( $\alpha$-D-glucosyl)-D-fructose)). Zeitschrift für die Zuckerindustrie 14, 309-315 and 375-383.

9. Schiweck H (1980) Palatinit ${ }^{\circledR}$ Herstellung, technologische Eigenschaften und Analytik palatinithaltiger Lebensmittel $\left(\right.$ Palatinit ${ }^{\circledR}$ production, technological characteristics and analysis of Palatinit-containing food). Alimenta 19, 5-16.

10. Schiweck H, Munir M, Rapp KM, et al. (1990) New developments in the use of sucrose as an industrial bulk chemical. Neue Entwicklungen in der Verwendung von Saccharose als Rohstoffe für die chemische Industrie. 1. Zuckerindustrie 115, 555-565.

11. EU Commission Decision 2005/581/EC of 25th July 2005 authorising the placing on the market of isomaltulose as a novel food or novel food ingredient under Regulation (EC) no 258/97 of the European Parliament and of the Council. Official Journal of the European Union of 29.7.2007, L199/90-L199/91

12. FDA (2006) US GRAS Notification no 0184 on isomaltulose.

13. Jonker D, Lina BAR \& Kozianowski G (2002) 13-Week oral toxicity study with isomaltulose (Palatinose) in rats. Food Chem Toxicol 40, 1383-1389.
14. Atkinson FS, Foster-Powell K \& Brand-Miller JC (2008) International tables of glycemic index and glycemic load values: 2008. Diabetes Care 31, 2281-2283.

15. Graham I, Atar D, Borch-Johnsen K, et al. (2007) European guidelines on cardiovascular disease prevention in clinical practice: executive summary. Eur Heart J 28, 2375-2414.

16. Cummings JH \& Wiggings HS (1976) Transit through the gut measured by analysis of a single stool. Gut 17, 219-223.

17. Gostner A, Schäffer V, Theis S, et al. (2005) Effects of isomalt consumption on gastrointestinal and metabolic parameters in healthy volunteers. Br J Nutr 94, 575-581.

18. Matthews DR, Hosker JP, Rudenski AS, et al. (1985) Homeostasis model assessment: insulin resistance and beta-cell function from fasting plasma glucose and insulin concentrations in man. Diabetologia 28, 412-419.

19. Sandberg AS, Ahderinne R, Andersson H, et al. (1983) The effect of citrus pectin on the absorption of nutrients in the small intestine. Hum Nutr Clin Nutr 37, 171-183.

20. Sandberg AS, Andersson H, Hallgren B, et al. (1981) Experimental model for in vivo determination of dietary fibre and its effect on the absorption of nutrients in the small intestine. Br J Nutr 45, 283-294.

21. Sandberg AS, Andersson H, Kivistö B, et al. (1986) Extrusion cooking of a high-fibre cereal product. 1. Effects on digestibility and absorption of protein, fat, starch, dietary fibre and phytate in the small intestine. Br J Nutr 55, 245-254.

22. Englyst HN \& Cummings JH (1985) Digestion of the polysaccharides of some cereal foods in the human small intestine. Am J Clin Nutr 42, 778-787.

23. Englyst HN \& Cummings JH (1987) Digestion of polysaccharides of potato in the small intestine of man. Am J Clin Nutr 45, 423-431.

24. Normén L, Laerke HN, Jensen BB, et al. (2001) Small-bowel absorption of D-tagatose and related effects on carbohydrate digestibility: an ileostomy study. Am J Clin Nutr 73, 105-110. Erratum in: Am J Clin Nutr 73, 665.

25. Liu S, Manson JE, Stampfer MJ, et al. (2001) Dietary glycemic load assessed by food-frequency questionnaire in relation to plasma high-density-lipoprotein cholesterol and fasting plasma triacylglycerols in postmenopausal women. Am J Clin Nutr 73, 560-566.

26. Amano Y, Kawakubo K, Lee JS, et al. (2004) Correlation between dietary glycemic index and cardiovascular disease risk factors among Japanese women. Eur J Clin Nutr 58, 1472-1478.

27. Slyper A, Jurva J, Pleuss J, et al. (2005) Influence of glycemic load on HDL cholesterol in youth. Am J Clin Nutr 81, 376-379.

28. Murakami K, Sasaki S, Takahashi Y, et al. (2006) Dietary glycemic index and load in relation to metabolic risk factors in Japanese female farmers with traditional dietary habits. Am J Clin Nutr 83, 1161-1169.

29. Opperman AM, Venter CS, Oosthuizen W, et al. (2004) Metaanalysis of the health effects of using the glycemic index in meal-planning. Br J Nutr 92, 367-381.

30. Jenkins DJ, Wolever TM, Kalmusky J, et al. (1987) Low-glycemic index diet in hyperlipidemia: use of traditional starchy foods. Am J Clin Nutr 46, 66-71.

31. Brand-Miller J, Hayne S, Petocz P, et al. (2003) Low-glycemic index diets in the management of diabetes: a meta-analysis of randomized controlled trials. Diabetes Care 26, 2261-2267. 